\title{
Towards a History of Speech Act Theory ${ }^{1}$
}

\author{
Barry Smith
}

From A. Burkhardt, ed., Speech Acts, Meanings and Intentions. Critical Approaches to the Philosophy of John R. Searle, Berlin/New York: de Gruyter (1990), 29-61.

\section{Introduction}

That uses of language not only can, but even normally do have the character of actions was a fact largely unrealised by those engaged in the study of language before the present century, at least in the sense that there was lacking any attempt to come to terms systematically with the actiontheoretic peculiarities of language use. Where the action-character of linguistic phenomena was acknowledged, it was normally regarded as a peripheral matter, relating to derivative or nonstandard aspects of language which could afford to be ignored.

The reasons for this are largely historical. In the first chapter of his De interpretatione, Aristotle writes:

Every sentence is significant [...], but not every sentence is a statement-making sentence, but only those in which there is truth or falsity. There is not truth or falsity in all sentences: a prayer is a sentence but is neither true nor false. The present investigation deals with the statement-making sentence; the others we can dismiss, since consideration of them belongs rather to the study of rhetoric or poetry. (17 a 1-5, Edghill translation)

Aristotle's attitude remained authoritative until the end of the nineteenth century. There are, certainly, medieval writings on sacramental and other ritual and quasi-legal uses of language, as for example in connection with the issue as to what is involved in the constitution of a valid baptism or marriage. But such writings contain at best isolated passages capable of being interpreted with hindsight as belonging to a theory of speech acts. They exerted no wider theoretical influence in their own right, and they did not succeed in bridging the gap opened up by Aristotle between logical and other ("poetical") aspects of language use. The first philosopher to have fought consciously and explicitly against the Aristotelian conception seems to have been Thomas Reid, ${ }^{2}$ who saw that there are, in addition to judgments, also other types of sentence permitting of a theoretical treatment. The principles of the art of language are, he wrote,

to be found in a just analysis of the various species of sentences. Aristotle and the logicians have analysed one species - to wit, the proposition. To enumerate and analyse the other species must, I think, be the foundation of a just theory of language. $(1894$, p. 72$)$

Reid's technical term for promisings, warnings, forgivings, etc., is "social operations". Sometimes he also calls them "social acts", and opposes them to "solitary acts" such as judgings, 
intendings, deliberatings and desirings, which are characterised by the fact that it is not essential to them that they be expressed and by the fact that their performance does not presuppose any "intelligent being in the universe" in addition to the person who performs them $(1969$, p. 71 ; 1969a, p. 437).

Social acts, as Reid conceives them, are neither modifications nor combinations of solitary acts. They form a separate field of investigation, above all because expression belongs to the very essence of the social act, and this expression is therefore radically different from that sort of accidental expression which we sometimes find in the field of solitary acts. A command is not "a desire expressed by language" (1969a, p. 61). A promise is not "some kind of will, consent, or intention, which may be expressed, or may not be expressed" (op. cit., p. 453). Social acts are such as to have a necessary directedness towards some other person, and the relevant linguistic expression makes sense only where such a directedness obtains. In a promise, for example, "the prestation promised must be understood by both parties" (op. cit., p. 446). Social acts thereby constitute a miniature "civil society", a special kind of structured whole, embracing both the one who initiates them and the one to whom they are directed. The latter "acts a part in them" (op. cit., p. 438), and this part is indispensable to the existence of the whole.

Reid has hereby captured many of the most important elements of the modern theory. Unfortunately, his Cartesian (dualist) ontology meant that he was unable to give a clear and consistent statement of the relation between observable utterance and underlying intention or act of will. ${ }^{3}$ Reid's account is incomplete also in that he concerns himself only with the structures of what one might call unimpaired social operations. He pays no special attention to cases of possible "infelicity". Not least important however is the fact that his work on social acts remained without any influence in the wider philosophical community, so that it was not until the end of the 19th century that the idea of linguistic action began to rear its head once more. Pertinent remarks may, again with the benefit of hindsight, be extracted from the writings of Peirce, though here, too, one will search in vain for any developed theory of the way uses of language may effect "a general mode of real happening" 4 . It is rather in the work of the Munich phenomenologist Adolf Reinach (1883-1917) that there is to be discovered the first systematic theory of the phenomena of promising, questioning, requesting, commanding, accusing, etc., phenomena which Reinach, like Reid (though almost certainly independently ${ }^{5}$ ), collects together under the heading "social acts".

Reinach's work provides a rich taxonomy of the various different speech action varieties and of their possible modifications. ${ }^{6}$ It contains a detailed treatment of the quasi-legal status of speech actions and of the relations between legal and ethical obligations. And it contains a discussion of one feature of speech actions which seems hardly to have been dealt with in the Anglo-Saxon literature - that feature whereby such actions may be performed by proxy, as when an action of promising or commanding or inviting is carried out by one person in the name of another. ${ }^{7}$

Reinach's work did not, however, spring from out of nowhere, and we shall be in a position to understand the nature of his contribution only when we have devoted some time to an examination of the Brentanian-Husserlian background from out of which it grew.

\section{Judgments and Propositions: Some Necessary Distinctions}

For a theory of speech acts to become possible, it was necessary for philosophers and linguists to carve out for themselves a clear conception of judgment, and above all of the difference between judgment on the one hand and concept or idea or presentation on the other. Here again, 
Aristotle's running together of the two sorts of phenomena ${ }^{8}$ had long exerted an almost unshakeable hold, and it was only in the modern period, especially with the work of Bolzano, Brentano, Frege and Husserl, that philosophers and linguists finally moved away from a conception of judgment as a matter of the association or linking together of ideas or concepts to views of judgment as acts sui generis, with their own "propositional contents". 9 Here a double achievement was necessary: judgment and concept had to be distinguished not only from the point of view of logic, but also psychologically. Only then could the separateness and concomitant interdependence of (semantic) content and (pragmatic) force be explicitly acknowledged, and only then could the latter become a proper object of study in its own right (where linguists had earlier been confined in their treatments of such matters to rather superficial remarks on sentence-melody and intonation).

The logical distinction between judgment and concept had been familiar, certainly, to some medieval philosophers, but it had been subsequently lost. Bolzano, with his doctrine of the canonical form of propositions in themselves ${ }^{10}$, had done much of what was necessary to reinstate it. But Bolzano's account of the underlying psychology is far from clear ${ }^{11}$, and even Frege's Begriffsschrift (1879) still retains elements of the traditional conception of judgment as a matter of the "combination of ideas". ${ }^{12}$ Brentano, on the other hand, was psychologically more sophisticated, and along with his disciples Marty and Stumpf he drew a psychological distinction not merely between judgment and idea as acts but also between the corresponding contents in the minds of judging subjects. Not merely is judging or believing to be distinguished from any combining together of concepts; that which is judged or believed, too, is to be distinguished from the result of any such combining. The contents of judgments are however understood by the more orthodox Brentanists in a too narrowly psychological way, and this did much to stave off sophistication on the logical front.

It was in fact Husserl who saw that it was possible to put the psychological discoveries of the Brentanists to work in a properly logical framework (the latter inspired in part by Bolzano). This necessitated however a new distinction between the immanent content of an act on the one hand and its ideal content (or content-species) on the other, the two sorts of content being related, roughly, as the triangle scratched in the sand is related to the ideal or abstract triangle of the geometer. Bolzano and Frege, by turning aside from questions of psychology, had left themselves in a position where they were unable to do justice to the relations between, on the one hand, those ideal contents which make up the subject-matter of logic, and, on the other hand, our thinking acts themselves (including those thinking acts bound up with acts of language). The applicability of logic to empirical thinkings and inferrings is thus rendered all but inexplicable in their work, as in that of many of their modern-day successors. Husserl, in contrast, by emphasising the link between immanent and ideal content, was able to account for this applicability without at the same time falling back into a psychologism of the sort accepted by the Brentanists.

An ideal content is for Husserl the immanent content of an act taken in specie. The ideal content of an act of presentation might be called a concept; the ideal content of an act of judgment might be called a proposition.

The significance of the move to a concept of proposition as ideal or abstract entity, whether in Husserl's, in Bolzano's, or in Frege's sense, will be clear. Above all, it made possible a conception of propositions as entities capable of being manipulated in different ways in formal theories. But it made possible also a conception of propositional contents as replaceable parts, capable of becoming combined together in different contexts with complements of different 
kinds. We can judge and believe that a given proposition is true; but we can also regret that it is true, and we can wish or command or request that it be true, and so on. ${ }^{13}$ As the Munich phenomenologist Alexander Pfänder pointed out in his "Logik" (1921), a work inspired by Husserl, there is a veritable plethora of such "thought formations" or "Gedankengebilde" - he mentions questions, assertions, reports, thankings, recommendings, requests, warnings, allowings, promisings, invitings, summonings, incitements, prescribings, orders, decrees, prohibitions, commands, laws (cf. op.cit, p. 149) - which share with judgments just those "propositional contents" which form the subject-matter of logic.

\section{Husserl and the Theory of Objectifying Acts}

Brentano, as is well known, had defended the thesis that all mental acts are intentional, i.e. (in one of a range of possible formulations) they are given to their subject as directed towards an object (though there need not in every case be an existent object toward which they are directed). Another way of formulating this thesis is to say that every mental act is either the "presentation" of an object or it is founded on such a presentation. ${ }^{14}$ Husserl exploited this thesis in various modified forms in the Logical Investigations, above all in the principle: every intentional experience is either an objectifying act or has such an act as its foundation. ${ }^{15}$ An objectifying act is an act which is given as fixing upon or as being targeted towards an object. Now, however, "object" is understood more widely than is the case with Brentano. The range of objectifying acts for Husserl includes:

1) acts directed towards individual things, events, processes, etc., and towards the parts and moments of these;

2) acts directed towards species or essences, and towards ideal objects such as numbers;

3) acts, above all acts of judgment, directed towards Sachverhalte or states of affairs. It is not our business here to provide a more precise formulation of this 'directed towards', and the reader is invited to select his own favourite theory of intentionality in what follows and to bend the text accordingly. Important is merely that objectifying acts are contrasted with emotional acts (feelings of love, hate, fear, acts of will, and so on), in that the latter are one and all founded on supplementary objectifying acts, which provide them with their objects. Each objectifying act has a certain internal structure. Above all, it manifests the two mutually dependent moments of quality and immanent content. ${ }^{16}$ The quality of an objectifying act concerns the manner in which the act itself is intentionally targeted towards its object: signitively or intuitively, in perception or in phantasy. The immanent content of such an act concerns the manner in which the object is presented in the act: as an urn or as a pot, as a bird or as a greater crested grebe, as $2+3$ or as the cube root of 125 . Thus if I first of all surmise and then judge and then doubt that John is happy, then that John is happy expresses the common immanent content of my successive acts, which may be assumed to differ only in respect of their quality. Husserl's theory of language and of linguistic meaning is based on this theory of objectifying acts. Language is first of all seen as having meaning only to the extent that there are acts in which meaning is bestowed upon specific expressions in specific sorts of intentional experiences. ${ }^{17}$ The acts which are capable of giving meaning to our uses of language must in every case, Husserl argues, be objectifying acts: the acts whose species are linguistic meanings are in every case acts of "representation" or "object-fixing". We can put this point in a more familiar terminology by saying that for Husserl all uses of language approximate to referential uses. More precisely: all expressions are associated either with nominal acts - which are directed 
towards objects in the narrower sense - or with acts of judgment - which are directed towards states of affairs.

This thesis has two aspects, of which the first need delay us only briefly: Husserl insists - in a way that will recall contemporary views of Frege, Russell and Meinong - that even syncategorematic expressions like and, or, if, under are referential in their normal occurrences of use, in the sense that they, too, have their own objectual correlates. They correspond to certain merely formal or abstract moments of complex structures of various kinds. Under, for example, is correlated with a certain spatial relation, and with a certain formal moment of combination. (Cf. 1900/01, pp. 297f., 305ff., Eng. pp. 502ff., 509ff.)

The second, and for our purposes more important, aspect of Husserl's thesis is concerned with uses of language in asking questions, issuing commands, expressing admonitions, requests, etc., and more generally with those aspects of language use - intimation, arousal, persuasion which would seem to fall outside the scope of a strictly representational theory. How, if uses of language must in every case get their meaning from representing acts, are we to cope with the meanings borne by non-representational uses of language?

Consider, first of all, the following passage from vol. I of Bolzano's Wissenschaftslehre:

A question [...] obviously does not say anything about that about which it questions; but it still says something: namely about our demand to receive instruction about the object about which we asked. And thus a question can be both true and false. It is the latter when it incorrectly renders this demand. (1837, $\S$ 22)

Bolzano hereby propounds a view of questions as disguised statements about certain mental acts or experiences on the part of the language-using subject. Husserl's own position might be seen as a generalisation of a view of this sort. ${ }^{18}$ My linguistic question Is John sitting down? is to be conceived as an abbreviated statement about a certain underlying non-linguistic act of questioning, a statement which ought to read in full: 'I am asking whether John is sitting down' or: 'My current question is whether John is sitting down.'

Applied to sentences used in making commands and in expressing wishes, this theory asserts that there is in each case a corresponding non-linguistic act or state of desiring, wanting, wishing, etc., running parallel with and normally outlasting the act or action of sentence-use. ${ }^{19}$ The objectifying act directed towards this non-linguistic act or state would then supply the meaning of the given sentence. Sit down on the chair! we could rewrite as: 'your sitting down on the chair is my current request'.

One might object against such a theory that an ordinary judgment must then equally serve as an abbreviation of "I'm currently judging that...", leading to an uncomfortable regress. This would however be to ignore the fact that where $S$ is $p$ and I judge that $S$ is $p$ quite clearly have different truth conditions, there is no parallel logical difficulty standing in the way of our conceiving Is $S p$ ? and $I$ am asking whether $S$ is $p$ as equivalent in meaning. As Husserl himself would have it, the sincerity of a question (or of an expression of desire, etc.) coincides with the truth of the corresponding statement. (1900/01, p. 693, Eng. p. 851) And he might also have adverted to the fact that, if John asks Mary whether S is P, and Mary does not catch his meaning, then an appropriate explication by John would have precisely the form of Husserl's "I am asking whether S is p".

\section{Daubert contra Husserl}


A third member of the Munich school of phenomenologists, with Reinach and Pfänder, was Johannes Daubert, in many ways the most influential of all the early devotees of Husserl's Logical Investigations, Daubert has provided us in particular with a detailed treatment of Husserl's views on linguistic meaning, which is contained in a letter to one of his fellow phenomenologists in Munich. ${ }^{20}$ The letter is interesting both because of the intrinsic importance of the issues with which it deals, and also because it shows that, already in 1904, there was a certain tradition in Munich of discussing problems associated with questions, wishes, commands and other ways of doing things with words. Daubert himself, as his manuscripts reveal, played a considerable role in the development of this tradition, and his work can be seen as standing midway between the still strictly representational theory of Husserl and the full theory of performatives and their modifications put forward by Daubert's disciple Reinach in his work of 1913.

Husserl, as we have seen, sets out from an opposition between (1) an actually experienced wish, command or question, and (2) the act involved in asserting a corresponding sentence, whether in communicative speech or in silent thinking. (1) and (2) cannot be identical, for (2) is a linguistic act, an act bound intrinsically to a certain utterance and determined and shaped by the relevant sentence. The wish, in contrast, is lacking such fixed sentential structure (it is, as it were, psychologically more original, it unfolds itself in a different way in time, and it is not confined to the context of any given utterance). How, then, are the two acts related? How, in Daubert's words, "do the acts of wishing, questioning etc., which are in themselves nonobjectifying, enter into the meaning unity of the corresponding wish- and question-sentences?" The most obvious answer would see the wishing or questioning itself as finding its expression immediately in a corresponding wish- or question-sentence, so that the wish-sentence would get its meaning from the wish in just the way that the predicative sentence gets its meaning from an act of judgment. Such a view has the additional advantage that it enables the wish- or questioncharacter of the experience to be carried over directly to the linguistic act. For questioning, wishing, and registering are, on Daubert's view, essentially distinct, and these distinctions ought properly to be reflected also in the ways in which the corresponding sentences get their meaning. $^{21}$

A view along the lines suggested by Daubert is not open to Husserl, however, for it would bring the for him unacceptable consequence that in the one case it would be objectifying acts which would function as carriers of meaning, in the other case acts of quite other sorts - and this, he thinks, would open up too radical a difference of structure in the ways in which the two sorts of sentence get their meanings. Now, however, Daubert asks why

should one be forced to choose between either only objectifying acts or acts of every species whatsoever serving as meaning-giving acts. Certainly, when I say something, then I have some sort of consciousness of that which my words are supposed to say. But I doubt whether this consciousness has to be an objectifying act in the sense put forward [by Husserl] on p. 566. Would it not be possible that to a certain class of experiences there would pertain a quite specific sort of consciousness, and therefore also a specific act-species, analogous to, but yet different from, the objectifying acts? It seems to me to be in fact the case that our consciousness of feelings (wishes, acts of will, moods etc.) has this character.

When I wish something, according to Husserl, then it is only the objects wished for of which I am conscious within the wishing experience itself. I become conscious of the wish-character of my experience only when I reflect upon it, and it is this reflecting consciousness which gives meaning to the utterance of a wish. But surely I can for example ask whether $\mathrm{S}$ is $\mathrm{p}$ without it 
being the case that I must reflect on my experiences. Certainly I do not seem always to be explicitly conscious of any inner process when engaging in questioning acts. This objection is confronted in $\S 69$ of the sixth Investigation, where Husserl agrees that it is of course not the same thing for me to direct a question to someone else and to register my own questioning experience in reflection. He insists, nevertheless, that in questioning there is a questioning experience of which we are conscious in the sense that it is registered immediately in inner perception. And Husserl insists that it is this registering which is the objectifying act which finds its expression in the corresponding words.

Husserl must, however, avoid the counter-intuitive consequence that the relevant experiences seem, on his account, to fall apart into so many separate (reflective and non-reflective) bits. He therefore talks of the reflective experience in somewhat culinary terms, as something which "binds itself [...] to the experience itself to make a new complex." "As the expression sets itself in a unity with the intuited inner experience in the manner of cognition, there arises a complex, which has the character of a self-contained phenomenon." (1900/01, p. 690, Eng. p. 848) But as Daubert points out:

this alters nothing in the fact that the consciousness-character of the whole complex should remain that of a reflection on experiences. I have the impression that behind this newly "arisen" complex there [...] hides something like a fusion. But then this too would be to admit to a phenomenologically peculiar species of consciousness or "knowledge about" [Wissens-um], i.e. to a new special species of meaning-giving acts, alongside the objectifying ones. (Cf. Smith 1988, p. 133)

The term "fusion" signifies qualitative continuity, the absence of perceivable internal boundaries $^{22}$, and what Daubert is getting at here is that, if the reflective experience truly is "fused" to the pre-reflective experience as Husserl seems to require on pain of defending a counter-intuitive theory, then it will follow that it is only the resultant fused whole which will be capable of being experienced: access is denied, phenomenologically, to the parts fused together within it. This means, however, that the very idea that there are such parts implies a departure from the realm of what is given in experience.

Daubert's view, in contrast, is that we may rescue Husserl's theory without leaving the sphere of phenomenology, by admitting as meaning-giving acts not only objectifying acts but also acts or act-moments derived from the domain of pre-reflective awareness or "feeling" in the Brentanian sense. In this he was attempting also to move beyond the intellectualism of Husserl's Logical Investigations, which sees language as being built up exclusively on the basis of acts drawn from the sphere of cognition. At this stage, however, Daubert did not go beyond Husserl's act-based theory to provide an account of questions, commands, etc., of his own which would do justice both to the act-moments of these phenomena and to their character as actions. ${ }^{23}$

\section{Anton Marty: Intimation and Arousal}

For all Daubert's objections, Husserl does clearly grasp the fact that our uses of language may accomplish more than mere representation. When I use a sentence to ask a question or issue a command, then on Husserl's view the complex of acts which is associated with my utterance is as it were complete in itself as far as meaning is concerned. The act which gives meaning to my utterance is a special objectifying act which has as its referent or objectual correlate my underlying non-linguistic act of questioning, desiring, etc. In another respect, however, he is willing to admit that my utterance is not self-sufficient. For it is of course directed to some alien 
subject, and it has in this respect an additional function, that of intimating to the hearer precisely that non-linguistic acts of the given sort are at the moment occurring:

Commands, like many other of the expressions here considered, have in the context of communication the function of saying to the hearer - in the manner of essentially occasional expressions - that the speaker is executing intimating acts (of request, of congratulation, of sympathy, etc.) in intentional relation to him. (1900/01, p. 689, Eng. p. 848)

Such expressions are peculiar and important not, however, because they have some special sort of "non-objectifying" meaning; rather, they have a "practical, and communicative" importance: "otherwise they are just accidental special cases of statements or of other expressions of objectifying acts" (1900/01, p. 692, Eng. p. 850). They are special first of all because the psychic subject is part of the content of the statement ("I request", etc.). But they are special also because they involve essentially indexical elements relating to this subject's current acts. Thus in a double sense they have the same features as are possessed, for example, by pronouns, tenses, deictical adverbs such as here and now, in that their meaning and reference depend on context or occasion of use. $^{24}$

Husserl sees such indexical intimation as being in a certain sense incidental to the workings of language. Some, however, argued that his account ought to be extended by a notion of deliberate intimation, by the recognition of a specifically communicative function of language. Thus in his "The Different Functions of the Word" of 1908, Hermann Schwarz defends an amended version of the Husserlian theory along the following lines:

The word [or sentence] names a state of affairs, an objectivity. It expresses a mental content, that is the given objectivity in the conception of the speaker. It intimates all kinds of inner happenings in the speaker of which he is normally not conscious, e.g. his thought-process of conceiving, all kinds of affects. And it communicates, in the function of deliberate intimating, that which the speaker wants to externalise of his own mental processes. In brief: the word is a true mirror both of the world of (logical) objectivities, and of the life of the mind, primarily through its naming function, then through its remaining functions. As something which expresses, it belongs exclusively to the province of thinking; as something which communicates, it belongs exclusively to the province of the will; and in the function of intimating it is filled with, among other things, elements from the life of feeling. (1908, p. 163)

Husserl himself however would on no account have been able to accept a view according to which the communicative function is essential to language. For language, Husserl insists, is still fully and in unmodified form present in silent speech - "in the solitary life of the soul" (1900/01, p. 690) - where there is not the slightest trace of a communicative function. Indeed it is this thesis which forces Husserl to hold on to the view that it is the representative function of intentional acts which can alone bestow linguistic meaning upon associated signs: a cat's purring may communicate or intimate all kinds of facts about the mental or emotional state of the cat, and in this sense it may be said to have meaning; but it does not have linguistic meaning, and this, Husserl would argue, can only be because it is not accompanied by representing (objectifying) acts.

Some order can perhaps be introduced into our deliberations here if we exploit the terminology suggested by Karl Bühler in his Sprachtheorie of 1934, a work which contains what is almost certainly the first occurrence of the term "theory of speech acts". Each and every use of language, according to Bühler, manifests one or more of the three functions of: 
- representation [Darstellung]

- intimation or expression [Kundgabe]

- arousal or appeal [Auslösung, "triggering"].

Expressed in these terms, Husserl's position amounts to the thesis that it is exclusively the function of representation which is the essential or defining function of language. ${ }^{25}$ Schwarz's position amounts to the thesis that the function of deliberate intimating has to be acknowledged also. The complementary position, which affirms that it is precisely the communicative functions of intimation and arousal which are essential to language, was put forward by Anton Marty. ${ }^{26}$ Marty, too, exerted an important influence on Reinach and on his fellow Munich phenomenologists, and the challenging and original ideas put forward by Marty in his philosophy of language anticipated also important elements of current investigations of cognitive and linguistic universals. To understand Marty's thinking, however, it is necessary to spend a few words on the "descriptive psychology" of his teacher Brentano. Brentano, as is well known, divided all mental phenomena into the three categories of presentations, judgments and phenomena of love and hate (the last category - referred to by Marty as the category of "phenomena of interest" - includes not only feelings but also acts of will). Marty, like Husserl, propounds an act-based theory of linguistic meaning, but it is a theory which draws directly on this Brentanian tripartite division of mental acts. Marty, that is to say, divides all (categorematic) linguistic forms into one or other of the three classes of names, statements, and what Marty calls "emotives" or "utterances calling forth an interest". ${ }^{27}$ Here he was doing no more than following in the footsteps of Brentano, who, already in 1885 in notes to lectures on logic, had written:

Speaking is often brought into opposition with acting. But speaking is itself an acting, An activity, by means of which one wants to call forth certain psychic phenomena. In the request and in the command the will to do something. Questioning and addressing belong here also: the one wants to determine the will to communicate something, the other to draw the attention to something that is to be heard. (Interest) In the cry a feeling, whether of pain, whether of joy, whether of amazement. In the statement one wants to call forth a judgment, etc. ${ }^{28}$

Marty himself, in his work on subjectless sentences of 1884, drew attention to the complementary function of intimation, i.e. to the fact that the words and sentences of a language may intimate psychic processes in the speaker (cf. esp. pp. 300f.). In his 1908, however, he echoes Brentano's view that:

The announcement of one's own psychic life is not the only, nor the primary, thing which is intended in deliberate speaking. That which is primarily intended is much rather a certain influencing or controlling of the alien psychic life of the hearer. Deliberate speaking is a special kind of acting, whose proper goal is to call forth certain psychic phenomena in other beings. In relation to this intention, the announcement of processes within oneself appears merely as a side-effect [párergon]. (1908, p. 284, emphasis added)

If, now, we define the meaning of a linguistic utterance as "that which is primarily intended in its use", then it will follow that a statement, for Marty, "has the meaning of awakening (insinuating, bringing about by suggestion) in the hearer a judgment of a given kind." "The statement means that the hearer should judge in a certain way." (Op. cit., pp. 286, 288.) But more: this intention is to be fulfilled not for example causally (by natural means), but linguistically, The primary intention on the part of the speaker lies in this: to generate a judgment in the hearer that is 
analogous to that which is as a rule expressed by the statement uttered. ${ }^{29}$ The caveat "as a rule" is designed to restrict relevant evocations to those which reflect the grammatical structure of the language used. But it is designed also to allow for the fact that the realisation of this primary intention is not a necessary presupposition of the understanding of the statement. It is sufficient that the hearer should gain a presentation of that judgment-content whose corresponding real judging the statement is normally used to awaken. Thus I can understand a statement even if I see through it as a lie, and I can speak of understanding a sentence even where I do not know that it is the actual utterance of some given person. All that is needed is the awareness that it is in general such as to awaken a judgment of a given sort (or, in the case of an utterance calling forth an interest, an emotion or an act of will). ${ }^{30}$

In defence of his arousal theory Marty criticises the objectification theory of requests, questions, commands, etc., put forward by Husserl in the Logical Investigations. He draws attention, in particular, to the fact that commands, requests, and so on, acquire on Husserl's theory the character of occasional expressions:

A command, a request for Husserl would be a statement [...] which would however, for the interpretation of its sense, stand in need of a support from its context similar to that which is required e.g. by the pronouns "I" or "this" [...] it would in each case have to be decided from the circumstances who issues a command and to whom. The command itself however would be a statement, a statement that commanding is taking place. $(1980, \text { p. } 369)^{31}$

This, however, has the consequence that, in order to understand the meaning of a command, one would need to call in aid facts pertaining to specific mental experiences of the commanding subject, facts which are surely not in every case relevant to the matter in hand. The scope of Marty's work is impressive. He mentions uses of language in asking questions, in issuing complaints, reprimands, requests, commands, recommendations, threats, in giving comfort, encouragement, praise (1908, pp. 364f.). And he hints at a recognition of the ethical dimension of his "emotives", but this in such a way that everything he has to say is referred always to the level of psychology. Thus he distinguishes those cases where a use of you should has the intention of awakening in the hearer a specific act of will, from cases where it has the intention of bringing him to feel something as good or bad in the ethical sense (op. cit., p. 376). He does not move on to grasp the legal or quasi-legal aspect which uses of language may involve, and he has no inkling of the distinction between what later came to be called 'illocutionary' and 'perlocutionary' acts. ${ }^{32} \mathrm{He}$ manifests no recognition of the association of (certain) linguistic utterances with formations such as claims and obligations. And therefore also his work contains no discussion of such phenomena as the promise. In relation to commands, similarly, he leaves aside the crucial role of the extra-linguistic and extra-psychological factor of authority. ${ }^{33}$ Thus he does not do justice to the phenomena of language action in all their aspects $^{34}$, and his contributions to our understanding of such phenomena are confined to partial insights which do not add up to a unified theory of the sort that we find in the work of Reinach, Austin or Searle.

Further inadequacies are pointed out by Bühler in his 1909 review of Marty's Untersuchungen, a review which was in turn extensively transcribed by Husserl in a manuscript of $1910 .{ }^{35}$ Bühler levies the charge - which ought by now to be familiar - that a dimension of Darstellung is indispensable if we are to do justice to those not insignificant uses of language which take place "in the solitary life of the soul": 
The question which meaning a linguistic unit has, [Marty] answers thus: it serves this or that intention to influence [...]. It follows as a consequence, however, that the thesis must be accepted that in all those cases where the primary intention of the speaker is neither an intention to influence nor an intention to express something, then there must be some other, new function of language at work. (Bühler 1909, pp. 964f.)

Bühler is prepared to accept what amounts to an emendation of Husserl's theory to the effect that certain words - nevertheless, although, and the like - have no Darstellungs-function, no function of representation, but are capable of being understood only in terms of intimation or Kundgebung (op. cit., p. 967). Here, too, however, it seems that Husserl could respond by pointing out that such words, too, have a function in the "solitary life of the soul", where no question of intimation can arise. In spite of the essential role in his theory of the notion of Darstellung, Bühler nevertheless concurs with Marty in his criticism of Husserl's representational theory of linguistic meaning. Husserl, as we have seen, had argued that where $p$ and I judge that $p$ have different truth-conditions, this is not true of $p$ ? and Iask whether $p$. Marty objects to this that the reason " $p$ ?" and "I ask whether $p$ " cannot have different truth-conditions is because the former has no truth-conditions at all. (Cf. 1908, p. 380) Marty, as we have seen, concludes that sentences expressing questions, wishes, commands, etc., do not represent, but rather intimate acts of the speaker and exert a determinate influence on the hearer. Bühler, now, is ready to concede that "this view finally solves all difficulties":

why should there not be sentences which have no representation-function? If one has already accepted that there are words of which this holds, then one will hold it possible for sentences, too. $(1909$, p. 973$)$

Bühler still finds it necessary however to challenge the psychological basis of Marty's approach. Thus he points out that we often grasp the objects or states of affairs represented by a speaker directly, that is without going through the detour of reflecting on his mental life (op. cit., p. 966). He objects also to the presupposition of Marty's theory to the effect that emotives relate directly always to certain mental processes, certain "phenomena of interest" in the hearer, and only indirectly to actions he may perform (an objection that is in some ways complementary to Marty's own objection to Husserl's "occasional" theory mentioned above). As Bühler puts it:

Marty himself sees the objection that the intended goal of certain commands clearly lies not in certain experiences of the hearer but rather in effects beyond the hearer. "Whoever, for example, commands: 'Speak louder!', does not essentially care that the person addressed has the inclination and will to speak louder. It suffices, if he does so. (Marty 365)" But Marty will not accept this objection: he appeals to the explanation that that which one does, is in general what one wants to do (op. cit., p. 970).

\section{Adolf Reinach: The Theory of Social Acts}

Reinach's own theory of social acts can be said to have developed through a combination of a logic, ontology, psychology and theory of language drawn from Husserl with insights derived both from Marty and from Daubert and his colleagues in Munich. An important role was played also however - especially in relation to Reinach's treatment of the action character of language and of the modifications or derivative or non-standard instances of social acts - by Reinach's background as a student of law. ${ }^{36}$ I shall concentrate here on Reinach's account of the action of 
promising, since it is in relation to this example that the inadequacies of the older act-based theories of linguistic meaning are most apparent. A wider perspective on Reinach's thinking is given by Crosby in his paper above.

On the traditional account (of for example Hume), the action of promising is seen as the expression of an act of will or as the declaration of an intention to act in the interests of the party in whose favour the declaration is made. The most obvious inadequacy of this account is that it throws no light on the problem of how an utterance of the given sort can give rise to a mutually correlated obligation and claim on the part of promisor and promisee. The bare intention to do something has, after all, no quasi-legal consequences of this sort, and it is difficult to see why things should be different in reflection of the fact that such an intention is brought to expression in language.

Both promising and communicating one's intention to do something, according to Reinach, belong to the category of what he calls "spontaneous" acts, i.e. acts which involve a subject's bringing something about within his own psychic sphere, as contrasted with passive experiences of, say, feeling a pain or hearing an explosion (1913, p. 706, Eng. p. 18). Certain specific types of spontaneous act, now, are such as to require as a matter of necessity a linguistic utterance or some other overt performance of a non-natural (rule-governed) sort. This does not hold of judging or deciding, nor even of forgiving, but it does hold of apologising, commanding, accusing. We may accordingly divide spontaneous acts into two classes, which we might call internal and external, according to whether the act's being brought to overt expression is a separable or inseparable moment of the relevant complex whole. ${ }^{37}$

Acts are divided further into self-directable and non-self-directable (the latter Reinach also calls other directed or "fremdpersonal"). Self-directable acts are such that the subject toward whom they are directed may be identical with the subject of the act (as in cases of self-pity, selfhatred, etc.). The latter, on the other hand, demand an alien subject, a subject other than the one who acts, toward whom they are directed (whether internally or externally). A peculiarity of certain acts manifesting the properties of being external and non-self-directable, now, is that they are such that the relevant utterance must of necessity not only be directed toward but also registered or grasped by the subject in question: a command must be received and understood by those to whom it is addressed (something which does not apply, for example, to an act of blessing, forgiving or cursing). A command, that is to say,

is an action of the subject to which is essential not only its spontaneity and its intentionality, but also its being directed towards other subjects and its standing in need of being grasped by those subjects. What has been said of commands holds also for requesting, admonishing, questioning, informing, answering, and many other types of act. They are all social acts which are, in their execution, cast by him who executes them toward another subject that they may break into his mind [einem anderen zugeworfen, um sich in seine Seele einzuhaken]. ${ }^{38}$ (1913, p. 707, Eng. pp. 19f.)

What is important about an action of this kind, now, is that it

is not divided into the self-sufficient execution of an act and an accidental statement [Konstatierung]; rather it constitutes an inner unity of deliberate execution and deliberate utterance. The experience is here impossible in the absence of the utterance. And the utterance for its part is not something that is added thereto as an incidental extra; rather it stands in the service of the social act and is necessary in order that this should fulfil its announcing function [kundgebende Funktion]. Certainly there exist also incidental statements relating to social acts: "I have just issued the command." But such statements then relate to the whole social act, with its external aspect (op. cit., p. 708, Eng. p. 20). 
Social acts, then, for Reinach exactly as for Reid, involve

activities of mind which do not merely find in words their accidental, supplemental expression, but which come to expression in the act of speaking itself and of which it is characteristic that they announce themselves to another by means of this or some similar external appearance. (Op. cit., p. 728, Eng. p. 36.)

The closeness to Austin and later speech act theorists is unmistakable. A promise cannot be the expression or intimation of an act of will or of an intention, because the acts which underlie a promise are such that they are simply not able to exist outside the compass of a whole of just this sort. And similarly there is no independent and self-contained mental experience which is somehow brought to expression in the issuing of a command. (Hence, a fortiori, a social act cannot be a mere report on such an experience.) It is none the less true that actions of promising and commanding possess not merely an external dimension of utterance and execution, but also an internal dimension: they are tied into the domain of mental acts. The given phenomena are further such that they presuppose or are founded on appropriate mental states, ${ }^{39}$ and also on states of other kinds - for example of authority.

We are far from having dealt with every aspect of Reinach's theory of social acts. Thus we could have considered his treatment of conditional acts ${ }^{40}$, of sham and defective and incomplete acts, of acts performed jointly and severally, and of that sort of impersonality of social acts that we find in the case of legally issued norms. As already stated, Reinach's theory is embedded within a larger theory of legal (and ethical) ${ }^{41}$ formations in general and of the ways in which legal essences may become modified in their instantiations as a result of the contingent and pragmatically motivated issuances of the positive law. It is not our business here, however, to stray into these aspects of Reinach's thought.

\section{A Priori Structures}

Whether Reinach's work exerted a direct or indirect influence on the development of speech act theory in Oxford is a question not yet able to be decided. ${ }^{42}$ More important for us here is the question as to what might be the theoretical significance of the Reinachian theory. In this connection I should like to suggest that Reinach has demonstrated that there is an alternative to the usual assumption that the philosopher's treatment of speech act phenomena must belong exclusively to the province of logic and philosophy of language. Reinach's work shows that speech acts and related phenomena may be treated ontologically, in a way which can yield a general theory of the given structures, a theory embracing within a single frame not merely their linguistic and logical aspects but also psychological, legal and action-theoretic moments of the phenomena in hand. Promises, claims, obligations, etc., are, on this view, entities of special sorts. They are part of the stock of the world, and not, as many analytic philosophers have been wont to assume, mere reflections of our ways of speaking about other, more humdrum entities. From the Reinachian point of view speech act theory is a descriptive science of the phenomena in question.

As Brettler puts it in her comparison of the work of Reinach and Austin:

There are numerous [...] points where Austin's work in the end confirms Reinach's conclusions, but by contrast the former shows itself to be fragmentary, to lack a sufficiently global approach to the speech act. The stages of analysis presented by How to Do Things with Words appear to fall from a 
phenomenological point of view within the stage of concept and word analysis preliminary to analysis of the essences themselves. (1973, p. 190)

But how are we to understand this rather opaque talk of an "analysis of the essences themselves"? Are we not here courting the Scylla of essentialistic Platonism having avoided the Charybdis of an overly exclusive orientation around the representing act? Certainly Reinach himself would insist that his deliberations relate to phenomena of a perfectly familiar and homebaked sort, not to other-worldly entities à la Plato. But to see this we must properly understand what he means by "essences" and "a priori laws". How, in particular, does Reinach exploit these notions in giving an account of the way in which a promise gives rise to a mutually correlated claim and obligation?

From the Reinachian perspective, as we said, the world contains promisings, obligatings, claims, commands, and relations of authority, just as it contains instances of biological and logical species such as lion and tiger or judging and inferring, As Husserl saw in his 3rd Investigation $^{43}$, the species which people the world can be divided into two sorts. On the one hand are independent species whose instances require specific instantiations of no other species in order to exist. Lion might be taken as an example of an independent species in this sense. ${ }^{44}$ On the other hand are dependent species whose instances do not exist in and of themselves but only in association with instances of complementary species of determinate sorts. As Husserl puts it:

It is not a peculiarity of certain sorts of parts that they should only be parts in general, while it would remain quite indifferent what conglomerates with them, and into what sorts of contexts they are fitted. Rather there obtain firmly determined relations of necessity, [...] determinate laws, which vary with the species of dependent contents and accordingly prescribe one sort of completion to one of them, another sort of completion to another. (1900/01, pp. 244f., Eng. 454)

Judging is an example of a dependent species in Husserl's sense: a judging exists only as the judging of some specific subject (as a smile smiles only in a human face). Promising, too, is an example of a dependent species. Here, however, we see that the dependence is multifold: a promise requires that there be also at least the species claim, obligation, utterance and registeringact, reticulated together with language-using subjects within the framework of a single whole of a quite specific sort. ${ }^{45}$ Moreover, the mental acts which underlie a promise are themselves such that they are not able to exist outside the compass of such a whole. Hence we have to deal here with a relation of two-sided dependence: the promise is as a matter of necessity such that it cannot exist except in association with an intending act, but this intending act is itself of a special (promising) sort and is as a matter of necessity of such a nature that it can exist only in the framework of the given whole. It is only superficially similar to an intending act of the sort that can exist outside the framework of a promise.

Promising involves, then, a certain sort of structure in reality, and each such structure will consist of instances of given species reticulated together in specific ways. Such structures can be understood on two distinct levels. On the one hand they are structures among the corresponding species, species which may be realised, in principle, at any time or place. In this respect the given structures, too, have the character of universals. Further, the dependence relations which tie the structures together have the character not of contingent associations but of necessary laws. The structures themselves, on the other hand, exist only in re, i.e. to the extent that their constituent species are instantiated here and now in some region of empirical reality. ${ }^{46}$ The structures in question are therefore both necessary and universal. Now as is well known, 
Kant had specified "necessity and strict universality" as "sure and certain marks" of the a priori which "belong together inextricably" ". Kant's remarks to this effect are of course formulated within the wider context of his own epistemological theory of the a priori. Reinach, however, turns the tables on Kant. He exploits the features of necessity and strict universality as the basis of an ontological theory of what he calls "a priori structures" or "apriorische Gebilde". Such structures may indeed have certain epistemological peculiarities. These, however, Reinach wants to have regarded as a mere consequence of their necessity and universality as ontologically conceived.

Thus Reinach is ready to concede that we do seem to have a special kind of cognitive access to (many) structures of the given sort. ${ }^{48}$ That a promise cannot exist except in association with mutually correlated claim and obligation seems to be something we know not merely through experiment and induction ("a posteriori", in the usual epistemological sense of this term). This fact is rather something that seems to possess an intrinsic intelligibility of its own: it can be grasped immediately, in the way that we grasp, for example, that blue is not a shape, or that nothing can be simultaneously red and green all over. But this intelligibility flows, Reinach argues, from the universality and necessity of the structures in question, which transcend any given factual realisation (something which applies also to the intelligibilities we associate for example with basic geometrical structures such as triangle and square). For Reinach (and also for Husserl) such intelligible structures may call forth entire scientific disciplines, including what Husserl and his Munich followers called "phenomenology", as well as Reinach's own a priori theory of law.

Husserlian phenomenology seeks to describe structures of this sort as they are to be found within the sphere of act-object relations. Reinach saw that the given structures may extend beyond this domain to embrace also entities from other spheres, including physical actions, entities of a linguistic sort, claims, obligations, and other, legal or quasi-legal formations. Interestingly, we have to deal here with entities existing in different ways in time. ${ }^{49}$ Obligations, claims and marital ties, on the Reinachian conception, are (relational and non-relational) states, and their dependence consists in the fact that they cannot endure unless their respective bearers exist. Acts and actions, on the other hand, are events or processes: their dependence consists in the fact that they cannot occur unless their bearers exist. If as a matter of fact certain actions are performed by a suitably authorised speaker under such and such conditions, then as a matter of necessity certain claims and obligations begin to exist. If as a matter of fact certain actions are performed by such and such suitably authorised persons under such and such conditions, then as a matter of necessity A and B become joined together as man and wife. We have here in each case a variety of what might be called laws of necessitation, for example of the form:

if an instance of species as a matter of empirical fact exists, then this is as a matter of necessity only in the framework of some larger whole in which species $\beta 1, \beta 2$, etc. are instantiated also. ${ }^{50}$

As this formulation makes clear, structures of necessitation are in a certain sense empirical: it is a contingent matter whether the relevant necessitating species or universals are in fact instantiated. If they are instantiated, however, then the relevant dependence relations obtain as a matter of necessity. The necessity in question is in this respect a hypothetical necessity, a matter of what linguists have come to call "implicational universals". ${ }^{51}$

If, now, certain species are necessitated, then it may be that the instantiation of certain other species will be as a matter of necessity excluded. Let us say that instances of species joined 
together within the framework of a single whole are "co-instantiated". We can now formulate laws of exclusion, for example of the form:

if an instance of species as a matter of empirical fact exists, then it is necessarily excluded that species $\beta 1, \beta 2$, etc. should be co-instantiated therewith. ${ }^{52}$

Thus there is an a priori law of exclusion which tells us that questioning whether $p$ excludes simultaneous knowledge that $p$ on the part of the questioning subject. ${ }^{53}$ Commanding that $p$ similarly excludes simultaneous requesting that $p$; seeing that $p$ excludes simultaneous imagining that $p ;{ }^{54}$ asserting that $p$ excludes simultaneous believing that not $p$; and so on. Dependence structures give rise also to what we might call laws of compatibility or of possibilisation:

if an instance of species as a matter of empirical fact exists, then as a matter of necessity species $ß 1, \beta 2$, etc. are capable of being co-instantiated therewith.

The acquisition of a claim, for example, brings with it the possibility of waiving the claim; an act of forgiveness brings the possibility of this act's being brought to expression; a disagreement brings the possibility of reconciliation, and so on.

Interestingly, since we are dealing here typically with structures unfolding in different ways in time, we may also have what might be called laws of a priori tendency ${ }^{55}$, where necessitation extends, as it were, forward into the future. Such laws might be of the form:

if an instance of species as a matter of empirical fact exists, then there is a necessary tendency for species $\beta 1, \beta 2$, etc. to be co-instantiated also.

Thus an act of willing or commanding or promising gives rise to a tendency that the content of the act be realised; the process of fulfilling a desire gives rise to a tendency that pleasure will ensue; the process of assenting to the premises of a valid argument gives rise to a tendency that one should assent to the conclusion also. But how can Reinach maintain that such relations are "a priori" in his, ontological sense? Certainly they have the same universality as the examples treated above (they are not restricted in their validity to some one specific place or time or culture). Their necessity, however, is merely what we might call a ceteris paribus necessity, in the sense that (in the terms of our formulation above): $\beta 1, \beta 2$ etc. will as a matter of necessity come into existence if there are no factors other than which are involved in determining their existence. A modified necessitation of this sort is, however, required if we are to do justice to, for example, the fact that a promise brings about a tendency on the part of the promisor to act in such a way as to realise the content of the promise; that a promise can be accepted or not accepted; that an act of promising tends to establish a moral obligation (and will in fact do so in the absence of other morally relevant factors); that an act of promising tends to be irrevocable (and will in fact be so in the absence of any special empowerment by the promisee), and so on all aspects of the promise which have been neglected in other, more standard treatments.

\section{John Searle: Institutional Concepts and Constitutive Rules}

Reinach's ontological theory of the a priori will of course not be easily swallowed by all philosophers, and there is a deep-rooted temptation to suppose that the given laws or structures 
have these special epistemological properties and are to be called "a priori" not for any ontological reasons but simply in virtue of certain logical relations among the corresponding concepts. Indeed from Kant to Searle there has held sway amongst philosophers quite generally a tendency to seek to view the a priori as something logical or epistemological tout court. As far as Reinach himself is concerned, such temptations are steadfastly to be resisted. We are not, he tells us,

proposing any theory of promising. We are only putting forth the simple thesis that promising as such produces claim and obligation. One can try, and we have in fact tried, to bring out the intelligibility of this thesis by clarificatory analysis. But to try to explain it would be just like trying to explain the proposition $1 \times 1=1$.

There is, Reinach goes on,

a fear of the given [Angst vor der Gegebenheit], a strange reluctance or incapacity to look in the eye what is ultimately intuitive and to grasp it as such, and this has driven unphenomenological philosophies, in relation to this as to so many other, more fundamental problems, to untenable and ultimately to extravagant constructions. (1913, p. 741, Eng. p. 46)

Searle, for his part, seeks precisely to explain the relation of promise and obligation by means of a theory of what he calls "constitutive rules". Such rules are a matter of arbitrary convention, at least in the sense that there are no special "essences" or "universal and necessary structures" by which they might somehow be constrained and which might serve to make them somehow intelligible. The illusion that there are such structures arises only as a result of the fact that we are able to ascribe "institutional concepts" to certain common or garden parts of the reality that has been shaped and affected by rules of the constitutive sort.

Consider, for example, the phenomenon we call signalling to turn left, This has the special significance it has, not because of some special essence or structure, but because more or less arbitrary rules have been adopted by the various empirically constituted societies of motorists, rules which bring it about that certain common or garden empirical events (flashing of lights, moving over to the left side of the road, slowing down, etc.) count as signalling to turn left and thereby come to be associated with these or those common or garden empirical consequences. Constitutive rules, then, may affect behaviour in such a way that this behaviour can be interpreted in terms of institutional concepts. But there are no special and supernumerary objects to which these concepts correspond. Promisings, for example, are just speakings which get counted out in a special kind of way (just as, for Hume, the causal relation is merely the result of a special way of grasping what is given in sensation).

We might summarise the differences between the Searlian and Reinachian approaches to the a priori structure of promise and obligation in a preliminary way as follows:

\begin{tabular}{|l|l|}
\hline Searle & Reinach \\
\hline $\begin{array}{l}\text { Obligation and promise are not separate } \\
\text { entities. As a result of the fact that we have } \\
\text { adopted certain constitutive rules in our }\end{array}$ & $\begin{array}{l}\text { Obligation and promise exist as items of } \\
\text { worldly furniture (albeit not as independent } \\
\text { items). They are instantiations of }\end{array}$ \\
\hline
\end{tabular}


speaking and acting, certain facets of this speaking and acting count as obligation and promise.

corresponding species or essences and the latter are capable of being investigated in and of themselves.

The supposition that obligation and promise exist as separate entities arises purely in reflection of the fact that we follow certain rules and are able to employ concomitant concepts in making sense of empirical reality.

Between obligation and promise there exist certain universal and necessary relations: the relevant concepts, and even the rules we follow in speaking and acting, have arisen in large part in reflection of these relations.

Our knowledge of the a priori truth that a promise gives rise to an obligation is knowledge obtained by an analysis of the concept of a promise (it follows logically from propositions relating to certain constitutive rules).

Our knowledge of the relations between promise and obligation is in some sense merely definitional, depending on certain institutional facts.

Our knowledge of such truths is knowledge of certain ontological structures in the world, structures which have both a universal and an individual aspect (and which may also enjoy a special kind of intelligibility).

Our knowledge of these relations is read off the world. These relations may involve (e.g.) linguistic elements, but they are not contributed by language.

The two doctrines seem superficially incompatible. As we shall see, however, the conflict between the Reinachian and Searlian conceptions is not so radical as might at first appear. Consider, for a moment, the universals of language research programme in linguistics. This has shown, in effect, that not just any old constitutive rules can become entrenched in our ways of speaking. Even given the all-pervading moment of convention in every natural language, there are structures in linguistic reality which are universal, structures which serve, as it were, as constraints on those linguistic conventions which may come to be established. And now it seems reasonable to suppose that there are universals of acting (and thinking) too, and that these universals will similarly constrain the possibilities of development among a variety of different sorts of human institutions. As in the linguistic sphere, such universals will typically be capable of being formulated as laws of necessitation, exclusion, etc., along the lines set forth above. Reinach's a priori theory of law may in this respect be conceived as a kind of universal grammar (or better: universal ontology) of the legal realm, or of human institutions in general. Reinach accepts however that certain purely conventional institutional conveniences may in the course of history come to be attached to structures such as promising, commanding, etc. as these are realised in particular societies. Thus he is willing to concede to Searle that even a world which manifests different sorts of a priori structures might still have room for purely conventional arrangements reflecting constitutive rules of the Searlian sort. ${ }^{56}$ Clear cases of concepts which are "purely conventional" in this sense can easily be found: endowment mortgage, marriage annulment, transferable pension right, and so on. These (we may reasonably suppose) correspond to no special structures or essences, but are read into the world in exactly the way described by Searle. The criterion of pure conventionality here, a criterion which 
Reinach, too, could readily accept, is the possibility of our defining the concepts in question in non-circular ways in terms of concepts which are unproblematically more basic. Even here, however, it seems clear that we must eventually arrive at basic institutional concepts, concepts not capable of being further defined on the institutional plane. Ownership, presumably, is a concept of this sort; others might be: obligation, benefit, gift, exchange, uttering, addressing, preference, sincerity, and so on. Perhaps even institution itself is a concept of this sort. One must resist the temptation to suppose that such basic institutional concepts can be defined in non-circular ways in terms of non-institutional concepts; for then all institutional concepts would turn out to be thus definable, an outcome which Searle quite rightly rules out. ${ }^{57}$ This residuum of basic institutional concepts delineates the subject-matter of Reinach's a priori theory of law. Already here, therefore, we can begin to see the sense in which the Searlian notion of constitutive rules might require some foundation in an ontological a priori of the Reinachian sort. For if Searlian constitutive rules are indeed involved in our activities of speaking and acting, then we know at least that reality itself must be dispositionally such that it can bear such rules, and the fundamenta of the relevant dispositional properties would then constitute an $a$ priori in re in the Reinachian sense. ${ }^{58}$

The notion of basic institutional concept seems, in any case, to be a notion to which both Reinach and Searle might conceivably be willing to give the time of day. Where they disagree is in relation to the question as to where the line is to be drawn between what we have called purely conventional concepts (concepts which can reasonably be held to have been introduced by definition), and basic institutional concepts (concepts for which non-circular definitions can be ruled out). Promising, in particular, is taken by Searle to be a purely conventional concept, where Reinach must insist that it is basic. And surely we must follow Searle in this. For has he not given a definition of "promising" in terms of other, more basic concepts? The definition reads as follows:

If a speaker $S$ utters a sentence $T$ in the presence of a hearer $H$, then, in the literal utterance of $T, S$ sincerely and non-defectively promises that $p$ to $H$ if and only if

1. normal input and output conditions obtain (e.g. that hearer and speaker both know how to speak the language and both are conscious of what they are doing).

2. $S$ expresses the proposition that $p$ in the utterance of $T$.

3. In expressing that $p, S$ predicates a future act $A$ of $S$.

4. $H$ would prefer $S$ 's doing $A$ to his not doing $A$, and $S$ believes $H$ would prefer his doing $A$ to his not doing $A$.

5. It is not obvious to both $S$ and $H$ that $S$ will do $A$ in the normal course of events (the act must have a point).

6. $S$ intends to do $A$.

7. $S$ intends that the utterance of $T$ will place him under an obligation to do $A$.

8. $S$ intends (i) to produce in $H$ the knowledge $K$ that the utterance of $T$ is to count as placing $S$ under an obligation to do A. $S$ intends to produce $K$ by means of the recognition of $i$, and he intends $i$ to be recognized in virtue of (by means of) $H$ 's knowledge of the meaning of $T$.

9. The semantical rules of the dialect spoken by $S$ and $H$ are such that $T$ is correctly and sincerely uttered if and only if conditions 1-8 obtain. ${ }^{59}$

The question is, however, whether we really do have before us a non-circular definition here. ${ }^{60}$ Consider first of all the terminology of "counts as" that is utilised by Searle e.g. in the locution "counts as a greeting". ${ }^{61}$ Suppose that, according to the practices of a certain auction house or race track lifting one's finger counts as making a promise. Does this mean that in such 
circumstances lifting a finger is making a promise? Clearly not, though the person who lifts his finger unawares may find that he is obligated just as much as if he had truly made a promise. (And suppose that in certain special auction houses raising one's left eyebrow counts as lifting one's finger; would this mean that my lifting my eyebrow unawares might here count as counting as making a promise?) What these examples show, is that the phrase "counts as" is normally used precisely in order to draw attention to the fact that performances may count as (say) making a promise even where the conditions necessary to promising fail to be met. One might, of course, rule out this connotation by speaking instead of what "counts correctly as a promise", but this, it seems, could mean nothing other than "is a promise", and it is just this locution which Searle is out to define. How, then, are we to give meaning to a phrase such as "counts as a promise" or "counts as a greeting" in a way which will meet Searle's requirements? How, in general, are we to make sense of talk of what counts as an X in the absence of any prior understand of what an X (in itself) might be? How could I ever come to know that such and such counts as a promise, unless I was independently familiar with promising itself? And what good would this knowledge be, even if it could be achieved? For if I know that something counts as X, and yet do not know what this ' $\mathrm{X}$ ' signifies, then surely I know nothing at all. Suppose, for example, that some Martian visiting Earth had conceived himself the project of realising the conjunction of Searle's conditions 1-9 without any familiarity with the Earthly institution of promising. Would he truly succeed in promising, merely as a result of having, in some way, met just these conditions as stated by Searle?

But now look what happens if we examine Searle's condition 1 in the light of the above. As Searle tells us (op. cit., p. 61), this condition is to be construed sufficiently broadly that, together with the other conditions, it guarantees that $H$ understands the utterance. But does this not mean that $H$ understands the utterance precisely as a promise? And does not the condition that speaker and hearer both "are conscious of what they are doing" itself presuppose their knowing that it is a promise in which they are involved? Searle must, surely, answer yes to these questions. But then his definition is circular.

Searle might however respond that we are imputing too lofty a purpose to the definition he has provided. His definition is not intended to throw light on any putative special "structure" of promising, any more than it is intend to provide a statement of the constitutive rules that were in fact historically involved in the genesis of corresponding institutions. Rather, he is offering merely a clarificatory analysis of the sorts of things we say about a certain not absolutely cleanly demarcated facet of behaviour. ${ }^{62}$ If his analysis is to be of value, however, then it must not neglect central features of the behaviour in question, and one such feature seems to consist in the fact that promising requires that one fit oneself naturally into a structured whole of the relevant sort. As Crosby stresses in his paper above, promising is not a composition of other acts, but an act in and of itself. Searle comes part way towards meeting this requirement in his thesis that the institution of promising, like all other institutions, is a "system of constitutive rules" (op. cit., p. 51). His problem, however, is that he cannot specify what "system" here might mean without once more casting himself upon the rock of some special Reinachian structure.

Perhaps one might circumvent this problem by describing the institution of promising in terms of the already mentioned notion of fusion. Perhaps Searle might want to argue that the fusion in question is a mere by-product of the process of entrenchment of institutions, something that is brought about as a matter of sheer Humean habit. What the Martian lacks, on this account, is merely a certain facility in simultaneous fulfilment of all the relevant constitutive rules. This, however, seems inconsistent with the awareness on the part of promisor and promisee of the 
special intelligibility (or naturalness, or tightness of fit) of the institution of promising, an intelligibility which flows, on the Reinachian view, from the universality and necessity of the corresponding structures. The Humean view is inconsistent also with the fact that the intentions referred to in conditions 6 and 7 stand to each other and to the associated utterance in a relation of necessary mutual dependence, so that, as Reid and Reinach would have put it, we have to do here with a very special kind of (syncategorematic) intending - with precisely that kind of intending which can occur only within the context of a promise properly constituted. Perhaps, then, Searle might argue that the necessary fusion or naturalness or spontaneity of realisation of the promise is guaranteed "semantically", by condition 9. This, however, would be to put the semantic cart before the horse of those speaking and acting subjects in whose behaviour a given dialect is realised. Which leaves, presumably, the option that Searle should add to his list an additional condition to the effect that the conditions stated be satisfied in a somehow natural way. But then what would this mean, other than that the activities in question are carried out in accordance with just that a priori structure of promising to which Reinach refers?

\section{Endnotes}

1. The essay which follows represents a heavily revised and expanded version of my "Materials Towards a History of Speech Act Theory" which appeared in Karl Bühler's Theory of Language (Amsterdam 1988), edited by Achim Eschbach. I am grateful to Professor Eschbach for his kind permission to reprint some of this material. I am grateful also to the Alexander von Humboldt Stiftung under whose auspices the original research was carried out, and to Graham Bird, Johannes Brandl, John Crosby, Kevin Mulligan and Karl Schuhmann for helpful comments. Page-references to English translations have been provided where available, though these have been amended as appropriate.

2. Cf. Schulthess 1983, p. 304; Mulligan 1987, pp. 33f.; Schuhmann/Smith 1990.

3. See Schuhmann and Smith 1990, §§ 5-6.

4. Cf. Peirce MS 517, pp. 36-38, as quoted in Brock 1981, p. 322. Brock seems, however, to exaggerate the extent to which Peirce can properly be said to have anticipated modern speech act theorists.

\section{Cf. Schuhmann/Smith 1990, § 1.}

6. See, now, the volume Speech Act and Sachverhalt, edited by K. Mulligan (1987), and especially Mulligan's own contribution to this volume.

7. See $\S 7$ of Reinach 1913; Burkhardt 1986 (pp. 20ff.); Brown 1987.

8. See e.g. De anima 430 a 27, De interpretatione 16 a 12, Metaphysics 1051 b 3.

9. This conception is still maintained e.g. by so notable a linguist as Hermann Paul, who defines

a sentence as "the linguistic expression [...] of the fact that the connection of several 
presentations or groups of presentations has occurred in the mind of the speaker and the means of bringing about the same connection of these presentations in the mind of the hearer." (1909, $\mathrm{p}$. 121) The same view is present also e.g. in the work of Lipps, Wundt and Sigwart. 10. $1837, \S 23$.

11. In $\S 19$ of the Wissenschaftslehre, Bolzano identifies without further ado what he calls an "asserted proposition" with the "thought of a proposition", and in the same section he comes close to identifying judging with a "presenting accompanied by a holding as true".

12. Thus in $\S 2$ Frege describes the "content of a judgment" as a "blosse Vorstellungsverbindung."

13. On this see already Abelard (1919), pp. 369f. See also Reinach 1913, pp. 806f., Eng. p. 106f. and note the parallels to Searle's account of these matters in terms of 'directions of fit' in his 1982.

14. Brentano (1924/25, vol. I, pp. 112ff.). On the notion of foundation and the associated notions of dependence, moment, complex, unity, etc., at work in the pages that follow, see the papers and bibliography in Smith (ed.) (1982).

15. Cf. 1900/01, Investigation V, $\S \S 37$ and 41; Investigation VI, $\S 13$.

16. We ignore for present purposes the additional moment of intuitive filling (cf. Husserl 1900/01, e.g. p. 566, Eng. p. 743, and the discussion in Willard 1984, pp. 218-32).

17. Husserl indeed identifies linguistic meanings in the more usual sense - that which is, for example, preserved in translation - with ideal contents or content-species of acts of the given sort. Linguistic meanings are the contents of language-using acts taken in specie. (Cf. Willard 1984, and Smith 1987 and 1988a.) As Husserl himself recognised, this account of linguistic meaning becomes problematic when we have to deal with uses of language involving "occasional" or "indexical" components (cf. Mulligan/Smith 1985).

18. Cf. 1900/01, p. 679, Eng. p. 839.

19. Act, here, refers to mental events of seeing, judging, deliberating, etc. Action I shall reserve for physical or bodily events of killing, waving, etc., and also for those speaking events (promisings, warnings, apologisings) which are otherwise normally referred to as speech acts, (Cf. Brentano 1924/25, vol. II, pp. 110f.)

The terminology of act and state, on the other hand, points to a different kind of opposition between what is episodic (for example acts of judging or deciding), and what endures (for example states of conviction or belief) (cf. Mulligan/Smith 1986). Brentano did not see the need to draw this latter distinction, and the Brentanian "judgment" therefore comprehends indiscriminately both episodic assertions and enduring attitudes of belief or disbelief. True clarity in this respect seems to have been first achieved by Reinach (1911).

20. The letter, which is to be found in Daubert's Nachlass in the Bavarian State Library in 
Munich, deals with ch. 9 of Husserl's sixth Logical Investigation. It comprises double folio 83 of Daubert's file A I 5, entitled "Husserl/Meinong". (Cf. Smith 1988, for a translation of relevant passages.) It was written on 28 December 1904 to Fritz Weinmann who was, with the other Munich phenomenologists, a student of Theodor Lipps.

21. As Daubert argued in his manuscript A I 2 on the subject of questions, Husserl's view that that which gives meaning to the question is an act of registering cannot be correct, for such an act of registering would be an objectifying act,

and this precisely contradicts the essence of the question. It is a contradiction to ask and to register in one and the same breath. The registering sentence would always have a sense quite other than the question, a sense which would not here come to direct expression. (p. 14v)

Cf. the detailed discussion of this manuscript in Schuhmann/Smith (1985). 22. The notion of fusion or Verschmelzung, which was exploited by Stumpf in his Tonpsychologie, recalls ideas of the so-called "chemical psychologists" in Britain in the 18th and 19th centuries. Cf. e.g. Brentano's discussion (1924/25, vol. 1, p. 126) of the work of William Hamilton.

23. Cf. Schuhmann/Smith 1985 and Smith 1988 for accounts of the subsequent development of Daubert's thinking on this matter.

24. Cf., again, Mulligan/Smith (1985) for an account of Husserl's views on occasionality/indexicality.

25. As Hellmuth Dempe points out in his dissertation on Bühler's philosophy of language:

either intimation [Kundgabe] belongs to language, and then that which is intimated is in the first place represented, meant intentionally in the sign; or the intimation is merely a causal function and then it is a sign in the same sense in which the state of the thermometer is a sign of the current temperature. $(1928, \mathrm{p}$. 86)

We must therefore, Dempe argues in defence of Husserl's unifunctional theory, distinguish intentional intimation, which is effectively representation, from representation-free causal intimation; and then "even causal intimation is [...] for the consciousness who observes the intimation, a sign for that which is intimated, that is, a representation thereof" (op. cit., p. 87). Cf. also Dempe 1935 and Bühler's reply (1936). 26. Bühler himself goes so far as to claim that Marty simply did not recognise the Darstellungs- function, a thesis which is belied for example by Marty 1908, pp. 291f., 374, 376. Cf. also Funke 1927, p. 137.

27. For Marty's account of emotives see chapter 5 of his 1908. It would take us too far afield to deal here with Marty's account of the meanings of syncategorematic expressions. 28. Logikmanuskript B2, p. 118, emphasis added; cf. Brandl 1987 on the content of Brentano's early logic manuscripts.

29. "A linguistic unit has this or that meaning [...] means for us: it is as a rule applied to (and within certain limits is also capable of) suggesting or insinuating a [psychic phenomenon] of a certain sort in the hearer" (1908, p. 286). 
30. Cf. 1908 , p. 362.

31. Cf. Gardies 1965.

32. Cf. Austin 1962, pp. 99ff., and section 2 of the paper by Crosby above.

33. This factor was explicitly recognised by Pfänder in his "doctrine of imperatives" (1909, pp. 313, 316f.).

34. Thus he sees threats as a sub-class of commands (op. cit., p. 365n.), and he sees questions both as a sub-class of expressions of wishes and also as a sub-class of commands (op. cit., pp. $366,368)$, errors of a sort which Reinach would never have made.

35. Cf. Schuhmann 1977, p. 138.

36. Cf. Schuhmann/Smith 1987, pp. 10-13.

37. Cf. 1913, pp. 707f., Eng. p. 20.

38. The echoes of Marty's theory will here be obvious. Consider, for example, Marty's assertion that our intention in using a sign is directed "towards exerting a certain influence upon or mastering of the life of the alien mind of the hearer" (Marty 1908, p. 284).

39. This view is recognised by Searle in his 1982, at least in the sense that he characterises "beliefs" and "desires" as semantic components of speech act concepts.

40. Cf. Mulligan 1987, pp. $78 \mathrm{ff}$.

41. See Burkhardt 1987.

42. We do know, however, that Austin's interest in German (and Austrian) philosophy in the 1930s and '40s was not confined to his work in translating Frege. Moreover, it is known that a copy of Reinach's Gesammelte Schriften was possessed by Gilbert Ryle and survives, with annotations, in the library of Linacre College in Oxford. (Cf. Smith 1987, pp. 205, 212.)

43. It is this work which forms the indispensable presupposition of all of Reinach's work on $a$ priori structures in the field of civil law. Cf. the papers collected together in Smith (ed.) 1982, and also Mulligan 1987.

44. A lion is at most generically dependent on, for example, instances of the species oxygen, water, and so on. One should resist the temptation to suppose that "dependence" and "independence" here can be understood purely as a matter of priority relations amongst corresponding concepts (or otherwise in purely epistemological terms; cf. e.g. Strawson 1959, pp. 17ff., 59ff.). Certainly there are such priority relations. Yet there are also relations of dependence between the objects which fall under 
given concepts, and the two sets of relations seem not in every case to coincide. Moreover, it is not at all clear that Strawson (for example) is correct in his (Kantian) assumption that conceptual priority relationships should in every case have priority over corresponding objectual relations. 45. As Austin recognised, every speech act is dependent on its surrounding circumstances (1962, p. 52). Cf. the structural diagrams on p. 142 of Smith 1988 and on pp. 60ff. of Mulligan 1987. Similar ideas are present also among the Gestalt psychologists (cf. Smith (ed.) 1988), and they are anticipated also, interestingly enough, by Thomas Reid (cf. Robinson 1976, e.g. p. 46). 46. As we shall see, such instantiation may be more or less perfect or felicitous and more or less subject to different kinds of extraneous modifying influences.

47. Cf. p. B4 of the introduction to the second edition of the first Critique.

48. Cf. his 1913, § 1 and 1921a.

49. These different ways of existing in time are marked linguistically in the differences of verbal aspect. Cf. Mulligan/Smith 1986, pp. 115ff., and Mulligan 1987, pp. 62ff. Compare also the treatment of "anergetic objects" in Smith 1988b.

50. Cf. Reinach 1913, p. 814, Eng. p. 113.

51. See e.g. Holenstein 1985.

52. Cf. Reinach 1913, p. 814, Eng. p. 113.

53. We are dealing here in every case with standard instances of the relevant essences: cf. Searle 1969, pp. 54ff., Smith 1987, pp. 189f., Mulligan 1987, pp. 76ff., and the references to Reinach there given.

54. Cf. Wittgenstein 1980, II, § 63.

55. Cf. Reinach 1913, p. 815, Eng. p. 114. My attention was drawn to this idea by Crosby (1979), who himself derived it from Spiegelberg 1960, pp. 195-205. Compare also the passages on a priori probability in Findlay 1961.

56. Cf. Reinach's distinction between a priori structures and "enactments" or "Bestimmungen" (legally issued norms) which for practical and other purposes may even overrule the legal a priori. (Cf. Seifert 1983, Paulson 1987, and also Reinach 1913, pp. 801f., Eng. p. 104, where the parallels between Reinach's notion of enactment and Searle's notion of constitutive rule are especially clear.) Reinach himself comes close here to something like the Saussurian opposition between langue and parole, so that he is able to account e.g. for the relations between promise and obligation in a way which involves looking beyond what holds of any single realised act: cf. Burkhardt 1986, p. 54.

57. 1969 , p. 56. Nor can this ineliminable residuum of institutional facts be dismissed as the product of a mere practical indispensability. For then the thesis that such and such institutional 
strata are practically indispensable would itself require a fundamentum in re, and this too would retain its own ineliminable institutional residuum.

58. It may be that this is part of what Searle is getting at when he asserts (op. cit., p. 186) that we could not throw all institutions overboard and "still engage in those forms of behaviour we consider characteristically human”.

59. Extracted from Searle 1969, pp. 57ff.

60. As Searle (1969, p. 56) points out, only certain forms of non-circularity are here at issue. He does nevertheless appear to hold that promising can be reduced in a non-circular way to more basic institutional concepts such as obligation, utterance, etc.

61. 1969, p. 49; cf. also Hoffmann 1987, pp. 97ff.; Crosby 1983, pp. 158f.

62. Cf. op. cit., pp. $54 f$.

\section{References}

Abelard, P. (1919), Logica Ingredientibus, Geyer (ed.), Münster.

Austin, J. L. (1962), How to do Things with Words. Oxford.

Bolzano, B. (1837), Wissenschaftslehre. Versuch einer ausführlichen und größtentheils neuen Darstellung der Logik mit steter Rücksicht auf deren bisherige Bearbeiter, Sulzbach. Partial Eng. trans. by R. George, Theory of Science, Oxford (1972).

Brandl, J. (1987), Brentanos Urteilslehre. Eine Studie über die logische Form von Akt und Inhalt. Forschungsstelle und Dokumentationszentrum für österreichische Philosophie, Graz. Brentano, F. (1924/25), Psychologie vom empirischen Standpunkt, 2 vols., with introduction and notes by O. Kraus, 2nd ed. Leipzig. Eng. trans. (1973) Psychology from an Empirical Standpoint. London.

Brettler, L. V. (1973), The Phenomenology of Adolf Reinach: Chapters in the Theory of Knowledge and Legal Philosophy. Dissertation, McGill University. Brock, J. E. (1981), “An Introduction to Peirce's Theory of Speech Acts”. In: Transactions of the Charles S. Peirce Society, 17, 319-26.

Brown, J. (1987), "Reinach on Representative Acts". In Mulligan, K. (ed.), Speech Act and Sachverhalt, 119-32.

Bühler, K. (1909), Rezension von Marty 1908, Göttingische gelehrte Anzeigen, 171, 947-79.

Bühler, K. (1934), Sprachtheorie. Die Darstellungsfunktion der Sprache. Jena (2nd ed. 1965). 
Bühler, K. (1936), "Das Strukturmodell der Sprache”. In: Travaux du cercle linguistique de Prague, 6, 3-12.

Burkhardt, A. (1986), Soziale Akte, Sprechakte und Textillokutionen. A. Reinachs Rechtsphilosophie und die moderne Linguistik. Tübingen.

Burkhardt, A. (1987), "Verpflichtung und Verbindlichkeit. Ethische Aspekte in der Rechtsphilosophie Adolf Reinachs", in K. Mulligan (ed.), Speech Act and Sachverhalt, 155-74.

Crosby, J. F. (1979), "Phenomenology and the Philosophy of Law: The A Priori Foundations of Civil Law", mimeographed.

Crosby, J. F. (1983), "Reinach's Discovery of the Social Acts". In: Aletheia, 3, 143-94. Dempe, H. (1928), Über die sogenannten Funktionen der Sprache. Ein Beitrag zur Sprachphilosophie im Anschluß an die Sprachtheorie Karl Bühlers, Dissertation, Jena, repr. as Was ist Sprache? Eine sprachphilosophische Untersuchung im Anschluß an die Sprachtheorie Karl Bühlers. Weimar 1930.

Dempe, H. (1935),’Die Darstellungsfunktion der Sprache”. In: Indogermanische Forschung, 53, 245-66.

Findlay, J. N. (1961), Values and Intentions. London.

Frege, G. (1879), Begriffsschrift, eine der arithmetischen nachgebildete Formelsprache des reinen Denkens. Halle.

Funke, O. (1927), Studien zur Geschichte der Sprachphilosophie. Bern. Gardies, J.-L. (1965), "La philosophie du droit d'Adolf Reinach". In: Archives de Philosophie du Droit, 14, 17-32.

Hoffmann, K. (1987), "Reinach and Searle on Promising - A Comparison". In: Mulligan, ed., Speech Act and Sachverhalt, 91-106.

Holenstein, E. (1985), Sprachliche Universalien. Bochum.

Husserl, E. (1900/01), Logische Untersuchungen, Halle. Collected edition as Husserliana vol. XVII (ed., E. Holenstein) and XIX/1, XIX/2 (ed., U. Panzer), The Hague 1975/1984. All references are to the second volume of the first edition, unless otherwise stated.

Husserl, E. (1910), Besprechung von Marty 1908. In: Deutsche Literaturzeitung, 31, Sp. 110610, repr. in: Husserliana vol. XXII, 261-65.

Marty, A. (1884), "Über subjektlose Sätze und das Verhältnis der Grammatik zur Logik und Psychologie. III: Von gewissen Unterschieden der sprachlichen Ausdrücke und speziell der Aussagen, die nicht den durch sie bezeichneten Gedanken betreffen ("innere Sprachform" und 
deren Wirkungen)". In: Vierteljahrsschrift für wissenschaftliche Philosophie, 8, 292-340, repr. in: Marty, Gesammelte Schriften, II.1, Schriften zur deskriptiven Psychologie und Sprachphilosophie, Halle 1918, 62-101.

Marty, A. (1908), Untersuchungen zur Grundlegung der allgemeinen Grammatik und Sprachphilosophie, vol. 1. Halle.

Mulligan, K. (1987), "Promisings and Other Social Acts: Their Constituents and Structure". In: Mulligan (ed.), Speech Act and Sachverhalt, 29-90.

Mulligan, K. (ed.) (1987), Speech Act and Sachverhalt. Reinach and the Foundations of Realist Phenomenology. The Hague.

Mulligan, K./Smith, B. (1985), "A Husserlian Theory of Indexicality". In: Grazer Philosophische Studien, 28, 133-63.

Mulligan, K./Smith, B. (1986), "A Relational Theory of the Act". In: Topoi, 5, 115-30. Paul, H. (1909), Prinzipien der Sprachgeschichte. Halle.

Paulson, S. L. (1987), "Demystifying Reinach's Legal Theory". In; Mulligan (ed.), Speech Act and Sachverhalt, 133-54.

Pfänder, A. (1909), "Imperativenlehre”. In: H. Spiegelberg und E. Avé-Lallemant (eds.), Pfänder-Studien. The Hague, 295-324.

Pfänder, A. (1921), "Logik". In: Jahrbuch für Philosophie und phänomenologische Forschung, 4, 139-494, and as Separatum, Halle 1921.

Pfänder, A. (ed.) (1911), Münchener Philosophische Abhandlungen (Festschrift for Theodor Lipps). Leipzig.

Reid, T. (1894), The Works of Thomas Reid. Edinburgh and London.

Reid, T. (1969) Essays on the Intellectual Powers of Man. Cambridge, Mass. and London.

Reid, T. (1969a) Essays on the Active Powers of the Human Mind. Cambridge, Mass. and London.

Reinach, A. (1911), “Zur Theorie des negativen Urteils”. In: Pfänder, A. (ed.), 196-254, repr. in: Reinach 1921, 56-102. Eng. trans. as "On the Theory of the Negative Judgment". In: Smith, B. (ed.), Parts and Moments, 1982, 315-77.

Reinach, A. (1913), "Die apriorischen Grundlagen des bürgerlichen Rechts", Jahrbuch für Philosophie und phänomenologische Forschung, I/2, 685-847, and as Separatum, (1913), and (1922),; repr. in Reinach Gesammelte Schriften (1921), 166-350. Eng. trans. as "The Apriori Foundations of the Civil Law", by J. F. Crosby. In: Aletheia, 3 (1983), 1-142. 
Reinach, A. (1921), Gesammelte Schriften, herausgegeben von seinen Schülern, with an Introduction by H. Conrad-Martius. Halle.

Reinach, A. (1921a), "Vortrag über Phänomenologie", first publ. in: Reinach Gesammelte Schriften (1921), 379-405. Eng. trans. as "Concerning Phenomenology" by D. Willard, in: The Personalist, 50, (1969), 194-211.

Reinach, A. (1988), Sämtliche Werke. Kritische Ausgabe mit Kommentar, 2 vols., K. Schuhmann/B. Smith (eds.). Munich and Vienna (in preparation).

Robinson, D. N. (1976), “Thomas Reid's Gestalt Psychology". In: Thomas Reid. Critical Interpretations, ed. by S. F. Barker and Tom L. Beauchamp. Philadelphia. 44-54.

Schuhmann, K. (1977), Husserl-Chronik. Denk- und Lebensweg Edmund Husserls, The Hague.

Schuhmann, K. (1987), “Johannes Dauberts Kritik der 'Theorie des negativen Urteils' von Adolf Reinach” in Mulligan, K. (ed.), Speech Act and Sachverhalt, 227-238.

Schuhmann, K./Smith, B. (1985), "Questions: An Essay in Daubertian Phenomenology". In: Philosophy and Phenomenological Research, 39, 763-93.

Schuhmann, K./Smith, B. (1987), “Adolf Reinach (1883-1917)”. In: Mulligan, K. (ed.), Speech Act and Sachverhalt, 1-27.

Schuhmann, K./Smith, B. (1990), "Elements of Speech Act Theory in the Work of Thomas Reid". History of Philosophy Quarterly, 7, 47-66.

Schulthess, D. (1983), Philosophie et sens commun chez Thomas Reid (1710-1796), Berne. Schwarz, H. (1908), "Die verschiedenen Funktionen des Worts". In: Zeitschrift für Philosophie und philosophische Kritik, 132, 152-63.

Searle, J. R. (1969), Speech Acts. An Essay in the Philosophy of Language. Cambridge.

Searle, J. R. (1982), Intentionality. An Essay in the Philosophy of Mind. Cambridge.

Seifert, J. (1983), “Is Reinach's 'apriorische Rechtslehre' more important for Positive Law than Reinach himself thinks?”. In: Aletheia, 3, 197-230.

Smith, B. (1987), "Husserl, Language, and the Ontology of the Act", in Buzzetti D. and Ferriani, M. (eds.), Speculative Grammar, Universal Grammar, and Philosophical Analysis of Language. Amsterdam, 205-27.

Smith, B. (1988), "Materials Towards a History of Speech Act Theory", in Eschbach, A. (ed.), Karl Bühler's Theory of Language. Amsterdam, 125-52. 
Smith, B. (1988a), "Logic and Formal Ontology". In: Mohanty J. N. and McKenna, W. (eds.), Husserl: A Textbook, Lanham, 31-68.

Smith, B. (1988b), "Brentano and Marty: An Inquiry into Being and Truth". In: Mulligan, K. (ed.), Mind, Meaning and Metaphysics. The Philosophy and Theory of Language of Anton Marty. Dordrecht/Boston/Lancaster (forthcoming).

Smith, B. (ed.) (1982), Parts and Moments. Studies in Logic and Formal Ontology, Munich. Smith, B. (ed.) (1988), Foundations of Gestalt Theory. Munich and Vienna. Spiegelberg, H. (1960), The Phenomenological Movement. A Historical Introduction, 2 vols. The Hague.

Strawson, P. F. (1959), Individuals. An Essay in Descriptive Metaphysics, London.

Stumpf, C. (1883/90), Tonpsychologie, 2 vols. Leipzig.

Willard, D. (1984), Logic and the Objectivity of Knowledge. Athens, Ohio.

Wittgenstein, L. (1980), Remarks on the Philosophy of Psychology, Oxford. 